\title{
FINISTERRA ANNUAL LECTURE: PLACING GENDER IN GEOGRAPHY DIRECTIONS, CHALLENGES, AND OPPORTUNITIES
}

JANICE MonK ${ }^{1}$

\begin{abstract}
Since the emergence of interest in gender in the late 20th century its significance has become widely, though unevenly, included in research, teaching, and applied work in human geography and related social sciences. This Finisterra Annual Lecture reviews aspects of engagement internationally - where and how work has developed, themes addressed, methods applied, and approaches to dissemination. It notes advances made and some continuing challenges.
\end{abstract}

Keywords: Gender; research and teaching methods; international differences.

RESUMO - LIÇÃO ANUAL DA FINISTERRA: O GÉNERO NA GEOGRAFIA. DIREÇÕES, DESAFIOS E OPORTUNIDADES. Desde a emergência do interesse pelos assuntos relacionados com as questões de género no final do século $\mathrm{XX}$, a sua importância foi-se expandindo, embora de forma desigual, na investigação, no ensino e no trabalho aplicado em geografia humana e nas ciências sociais relacionadas. Esta Lição Anual da Finisterra procura rever aspetos do envolvimento internacional - onde e como a investigação foi desenvolvida, temas tratados, métodos aplicados e abordagens de disseminação. Anotam-se avanços e alguns desafios permanentes.

Palavras-chave: Género; pesquisa e métodos de ensino; diferenças internacionais.

RÉSUMÉ - CONFÉRENCE ANNUELLE ORGANISÉE PAR FINISTERRA: GENRE EN GÉOGRAPHIE. ORIENTATIONS, DÉFIS ET OPPORTUNITÉS. Depuis l'émergence de l'intérêt pour le genre à la fin du 20ème siècle, sa signification s'est étendue, quoiqu'inégalement, inclue dans la recherche, l'enseignement et le travail appliqué en géographie humaine et en sciences sociales connexes. La Conférence Annuelle de Finisterra passe en revue les aspects de l'engagement international - où et comment le travail s'est développé, les thèmes abordés, les méthodes appliquées et les approches de diffusion. Sont notées les progrès réalisés et certains défis persistants.

Mots clés: Genre; méthodes de recherche et d'enseignement; différences internationales.

1 Research Professor, School of Geography and Development Research Social Scientist Emerita, Southwest Institute for Research on Women, ENR2 Building, South 4th floor, P.O. Box 210137, AZ 85721-0137, Tucson, USA. E-mail: jmonk@email.arizona.edu 


\section{INTRODUCTION}

Since its emergence in the 1980s, prompted by international feminist social, political, and intellectual movements, attention to the significance of gender has become widespread and diversified, though uneven, in research, teaching, and applications of geography beyond the academy. My reflections focus first on where and how engagement developed, in the process noting my first encounters in Portugal. I then move on to some directions in current work and some possible ways to move forward. My first experience in Lisbon was in 1998 for Regional Conference of the International Geographical Union (IGU) when the late Isabel Andre provided local leadership for participation by the Gender Study Group. The theme for the Group's sessions was "Gender, Migration, and Human Rights," a topic that is still important. Twenty geographers represented thirteen countries from western and eastern Europe, North America, Argentina, Israel, S. Africa, and Japan. We addressed national, international, regional, and local scales, aspects of citizenship and women's rights and empowerment, and also policies in rural and urban settings at various times from historical European colonialism to contemporary socialist and capitalist settings. We discussed citizenship, women's rights, and empowerment, themes that continue to be important. The Lisbon meeting was one of the earliest of the Study Group that had been somewhat warily approved by IGU leadership in 1988. Since then the field has expanded, and the Study Group advanced to status of a Commission, one that was recognized by the IGU in 2014 with the award of "Best Commission" the first to be thus honored from among the 40 Commissions then existing within the IGU. Two members of the group have since received IGU honors and one of the founding members, Joos Droogleever Fortuin of the Netherlands, currently serves as senior Vice President of the IGU (Huang, Monk, Fortuijn, Garcia-Ramon, \& Momsen, 2007). This history indicates both the significance now attached to gender studies and also the continuing importance of the theme we had addressed in Lisbon in 1998 - of gender, migration, and human rights.

\section{SOME GEOGRAPHIES OF THE DEVELOPMENT OF GENDER STUDIES IN GEOGRAPHY}

I will comment first on some aspects of when and where gender studies became evident in Geography and are represented currently. They surfaced as the movement for equality and advancement of women emerged internationally in the mid-1970s associated partly with a series of conferences sponsored by the United Nations Organization and that were continued into 1980s. By then, in a number of countries, we had recognized the low representation of women in academic geography or of their being limited to low ranks. In the United States, for example, in 1973 the then President of the Association of American Geographers, lamented "The Strange Case of the Missing Woman Geographer." (Zelinsky, 1973). Similar concerns were addressed a few years later about British and Canadian Geography (McDowell, 1979; Mackenzie, 1989). Research since has shown 
that women geographers in the United States had, however, been significant from the late $19^{\text {th }}$ to the mid- $20^{\text {th }}$ century in institutions designed to prepare school teachers but that they were not welcome when such programs were gradually transformed to offer postgraduate education (Monk, 2004). Maria Dolors Garcia Ramon and colleagues (Garcia-Ramon, Castañer, \& Centelles, 1988) documented that into the 1980s women employed in Spanish universities were mostly limited to low ranking positions associated with preparing teachers. Recent research in the US however (Monk, 2017), and perhaps elsewhere, has identified some women who attained senior positions as applied geographers in government agencies. I raise this theme partly because the University of Lisbon offers both geography and planning.

\section{CONTEMPORARY INTERNATIONAL PARTICIPATION IN GENDER STUDIES IN GEOGRAPHY}

When we look at the contemporary engagement internationally of geographers working on gender, or at least of those who are involved with the IGU Commission on Gender and Geography, we see substantial regional variations (Huang, Monk, Fortuijn, Garcia-Ramon, \& Momsen, 2017). Over 750 people now subscribe to the Commission's mailing list and receive its newsletter that is published twice each year in English, Spanish and French editions. These are available on a website created by a group of young and early career geographers that identifies itself as "YES!" (Young Early and Career Scholars) (https://igugender.wixsite.com/igugender). The distribution of the subscribers is uneven nationally reflecting not only the size of participation in the discipline. Especially notable are gaps in China and the Soviet Union that otherwise have large communities of geographers. Analysis of the program from the 2016 IGU Congress in Moscow showed that physical geography was strongly represented among Soviet presenters and that women speakers were included. Gender themes, however, were not taken up by Soviet geographers. Neither do I recall any gender-related presentations by Chinese geographers at the large IGU Congress in Beijing in 2015. Membership on the Commission's listserv is uneven across countries in Latin America, though there has been substantial growth in recent years in Brazil and increasing activity in Mexico. This participation suggests not only differences that reflect language but also differences in orientations within the profession.

Over time the Gender Commission has met in several parts of the world and from some of these events have come journal issues. They include one from the meeting in Israel in 2010 which led to an issue of the Israeli Hagar (Blumen, Fenster, \& Misgav, 2013) while another resulted from the meeting held in 2009 in the border region of Hungary and Romania where gender themes had been largely missing in geography. Co-edited by the Romanian host, Sorina Voiculescu, and Robyn Longhurst of New Zealand (2009) who was then chair of the Commission, a special issue of Annals of West University of Timisoara included articles on rural spaces, on institutional politics in diverse areas of public and private employment, and of themes such as the challenges of combining hou- 
sehold work and careers. The articles show ways that political regimes can have bearing on interest in gender. A second publication from discussions in Romania was a theme section of International Research in Geographical and Environmental Education (Monk, 2011). It noted that in some western countries as neoliberal political regimes became prevalent enrolment in undergraduate courses in geography that were gender-focused could be negatively affected as students sought more traditional offerings. Conversely, postgraduate participation was sustained where it could be supported by funding from external research grants. In the Romanian case, the scarcity of relevant teaching materials in the local language created a different challenge for undergraduate teaching though classroom discussions on gender interested students who were seeking to adapt to social and political change. On the negative side, however, a Romanian geographer engaging with gender research found that publishing on gender was detrimental to her promotion when she was evaluated nationally by more traditional colleagues.

In recent years an impressive amount of work on gender and sexuality is coming from Ponta Grossa in Brazil where colleagues initiated the journal Revista Latino-Americana de Geografia e Gênero (http://www.revistas2.uepg.br/index.php/rlagg) which has taken the important step of accepting articles in Portuguese, Spanish, and English. The Brazilian group has also published books such as Espaço, gênero e poder: conectando fronteiras (Silva \& Pinheiro da Silva, 2011) which includes some items originally presented at a conference co-sponsored with the IGU Gender Commission. The group has also published volumes including themes of gender, sexualities, ethnicities and race, for example that edited by Silva, Ornat, and Chimin Junior (2017).

Initiatives point to fostering international ties that strengthen gender studies elsewhere in Latin American geography. Conferences in Mexico have brought together geographers from Europe, Latin America and some from North America. An inaugural event in 2015 produced an edited book in Spanish (Ibarra y Escamilla Herrera, 2016) which offers reflections on the nature and development of gender research in Argentina, Brazil, and Mexico as well as in Spain, France, and Italy and on the German-language literature of Switzerland, Austria, and Germany, plus an overview of Anglo-American work. A second international conference in Mexico, which included the co-leadership of Joseli Maria Silva of Brazil, addressed theoretical and methodological issues on the theme "Geography, Gender and Sexualities" with critical reflections on the importance of spatial scales. In August, 2018, the Gender Commission will be involved in a conference in Montreal in collaboration with the Canadian Association of Geographers on the theme "Feminist Geographies, 2018: In/during Troubled Times: Dialogue, Intervention and Praxis" and also in sessions at the IGU Congress in Quebec City. Another Latin American Seminar on Geography, Gender and Sexualities will be held in Argentina.

You may wonder why I have not commented on the state of gender research and teaching in Anglophone regions. In some places it continues to thrive and to cross boundaries with other related specialties. Within the American Association of Geographers, for example, over 400 members were recently reported as belonging to the Geographic Perspectives on Women specialty group. It sponsored or co-sponsored 60 sessions at the 
2018 Annual Meeting of the Association. Interestingly, it is currently conducting a survey of members to inquire whether they would prefer a new name. In 1981, the Women and Geography Study Group was established within the British Royal Geographic Society/ Institute of British Geographers. By 2013 it had revised its name to Gender and Feminist Geography Research Group with goals of supporting feminist research and also raising the profile of women in the discipline (http://gfrg.org.about). The international commercially published English-language journal. Gender, Place and Cultures is in its 25th year in 2018. Founding co-editors were from Britain and the United States and editors have continued to be predominantly from Anglophone countries (including from Canada and New Zealand) though editorial board members have included scholars from, for example, Australia, France, India, Singapore and Switzerland. Authors of articles represent additional regions and abstracts are in Spanish and Chinese.

My task here, however, is not primarily to explore the politics or the gaps in international engagement of organizations, but to consider what gender studies have to offer and to open discussion on some of the challenges and opportunities of themes and methods that could be relevant to work by scholars outside Anglophone settings. As an example, I draw on initiatives of the Gender Group in Geography at the Autonomous University of Barcelona to illustrate how gender studies can be fostered and disseminated. The group has been exceptionally successful at the postgraduate level in securing external grant funds for research in both rural and urban settings as well as in hosting international conferences that enhance its local and international visibility and reputation. In 2006 for example, it organized a conference on developments and practices in "Feminist Geographies Around the World" bringing together geographers from east-central and western Europe, southeast Asia, Latin America, and Anglophone west Africa. The papers were published in English in the journal Belgeo along with a reflective introduction (Garcia-Ramon \& Monk, 2007). While the event enhanced international communication, the strategy of publishing in a journal sponsored by the Belgian Geographical Society, as a non-hegemonic Anglophone organization, presented some limits however, since it does not have the widespread visibility and advertising of the kind supported by Anglophone commercial publishers.

Academic politics can, however, also restrict dissemination of the wealth of research presented at conferences. A stimulating conference hosted by Lan-Hung Nora Chiang was held at National Taiwan University in 2007 under the auspices of the IGU Gender Commission. It addressed "Transnational Lives: Feminist Perspectives on Citizenship, Home, and Belonging." Participants came from the US and Canada, southeast Asia, Australia/New Zealand and a few from Europe. When it came time for publication (which was in English) in the Taiwanese Journal of Geographical Sciences only one article was submitted by an international participant who had been at the conference, Ragnhild Lund, a senior scholar from Norway who co-authored with a Sri-Lankan colleague, Fazeeha Azmi, who is identified as first author. They addressed the family and housing experiences of women who had returned to Sri Lanka following employment in the Middle East. To complete the issue articles were identified from authors who had not 
been at the conference: an early career scholar from the U.S., a Japanese man researching Japanese women clerical workers in Singapore, and a book review by an Indian geographer. Dr. Chiang also contributed from her own research on the path to integration in Canada by Taiwanese of middle-class female immigrants (Chiang, 2009). The experience speaks to pressures and priorities of scholars to publish in the high profile Anglophone journals. The case also illustrates related concerns of scholars outside Anglophone settings that their work is marginalized by practices that include reviewing systems which they see as expressions of Anglophone academic hegemonies.

Such practices alert us to the power of language and cultures in shaping the construction and evaluation of ways of knowing. In India, for example, domination of the natural sciences and priorities that research should be directed to supporting policy goals has commonly favored the use of quantitative over qualitative methods by geographers. It has had implications for the nature of research on gender themes, of what is accepted for publication and professional advancement, and also for the reception of work, including that conducted by Indian scholars, both within their own setting and how it is received by gender studies scholars in other regions who are attuned to other theoretical, conceptual and methodological modes of study (Datta, 2008; Monk \& Garcia-Ramon, 2013). There are ways, however for "internationalizing" gender research, community outreach, and teaching other than through individual initiatives. Later in this article I will offer an example of dealing with a bi-national collaboration and also of the complexities of dealing with Anglophone hegemonies in research publications and the significance of language in constructing thought and expressions. In addressing these themes I primarily offer examples from the discipline of geography, one that attends especially to "place."

\section{EMERGING THEMES}

Gender research continues to take up new challenges in its themes and methods. Whereas early work emphasized the lives of mid-life women and gender categories tended to be binary, the complexities of experiences and the range of settings considered has widened. It is also important to address to whom and how our work is disseminated. In terms of categories of people, it has expanded to address masculinity as well as femininity and a range of sexualities. It has continued to consider both urban and rural settings, and diverse economic contexts, from the so-called developed regions of western nations to the agricultural regions in non-western settings. The innovations are both methodological and in relation to dissemination of the research and in teaching. Current work moves beyond binaries. In particular the concept of "intersectionality" has come to be explored in research, in methodologies and teaching. Age, sexualities, ethnicity, class, citizenship, disabilities, educational levels, and other differences play into the ways people experience space and place. The theme of intersectionalities yielded extensive participation in an international conference sponsored by the Gender Group at the 
Autonomous University of Barcelona in 2016 and led by Mireia Baylina and Maria Rodó de Zarate. Speakers from an array of countries considered a range of settings, methodologies, and themes among which were studies on everyday life and daily uses of transportation, of care work, masculinities, sexuality, and political activism. Opening speakers included Margarida Queirós of the University of Lisbon. The conference attracted some 70 presenters from multiple countries from Iceland to New Zealand, Argentina to the Czech Republic, France to Brazil, the United States to India and others. Among themes addressed were mobilities, identities, religion in the secular city, environmental activism, access to housing, urban and rural life, planning issues, and relations in the classroom. The research methods ranged from use of GIS tools to interviews, observations, and interpretations of literary works. If this seems like a conglomeration, I would rather say that it represents richness and creativity and recognition of the diversity of people, places and ways of knowing.

Research in political ecology and environmental management can also integrate these perspectives and influence framing of research design and practice. The work and career of Italian-born geographer, Martina Caretta (2016), is a case in point. Based in a university in Sweden she completed her doctoral research on the practices of men and women in farming communities in Kenya and Tanzania studying differences in roles and tasks of women and men in each setting. A distinctive feature of her field research was to prepare summaries in graphic and simple written form using local languages of what she thought people were telling her. In a process she has labelled as "member checking" (Caretta, 2016) she shared these summaries for comments by local people in order to see how their interpretations compared with or modified her own. To offer further feedback, as well as to enrich her research, in later stages of the project she supported cross-national visits of some residents for comparative conversations between the Kenyan and Tanzanian sites. The resulting dialogues enabled the Kenyan women to learn from the Tanzanian women's approaches of practices that they considered would enhance their own work. Her methods and experiences in the project support her commitment to research that can not only add to scientific knowledge but can have positive social impact for those who are subjects. As an aside, I might indicate here that given current job opportunities in some settings in neoliberal academia Dr. Caretta has now moved from Europe and obtained a position in the United States at the University of West Virginia. She has recently co-authored an article on consequences of those political economies for early career women in academia (Caretta, Drodzewski, Jokinen, \& Falconer, 2018). Her current research continues to address aspects of gender relations in water resource management and also in extractive industries.

Another example of innovative methodology is the work of Yvonne Riaño (2016) a geographer originally from Colombia now employed in Switzerland. She includes biographical conversations in workshops with "marginalized elite" highly-skilled women immigrants. Such women are not commonly the subjects of research but they do face various forms of social exclusion. The resulting dialogues from the workshops have shown that the method offered spaces to the women for personal transformation while 
also widening understandings for academic research and for activities of the local community agency. She proposed that they can be important for developing community programs and efforts to influence policies.

My own experiences in an interdisciplinary collaborative research and community outreach project with Mexican colleagues (in sociology and anthropology) and with colleagues in public health addressed aspects of women's health at the Mexico-US border. It involved dialogue and multi-year relationships with diverse constituencies including community women health promotoras, with administrators of community health agencies, and with political appointees engaged with border health policies. In dialogues and workshops we not only learned of the priorities of the "professional experts" and administrators but were also able to offer support to promotoras via workshops and the creation of on-line resources to extend their existing sources (Manning, Denman, \& Monk, 2004). As a research team we also informally shared aspects of our personal lives that helped to sustain the work over a multi-year period.

\section{Ethics and Politics in Conducting and Disseminating Research}

Though academic reward systems may prioritize publication in academic books and journals, other models of dissemination are also important if our work is to have social, cultural, economic and political significance. Placing gender in the wider public arena bringing it to community agencies, political leaders, and to the press are arenas for collaboration on gender matters. The work of Canadian geographer Geraldine Pratt is particularly interesting both for the sustained relationships that she developed with the women in a Filipina community organization in Vancouver with aims of addressing their well-being and of supporting their political engagement as well as to draw attention to the multiple implications of an immigration policy that has admitted the women in order to recruit them as child care and household workers for Canadian families. One of her strategies involved developing a play for local audiences and then a film that included women from the organization. Community members and local audiences were positioned to reflect and develop their own political activism. The film has not only been shown locally and beyond, but most interestingly in Manila for audiences of those who had been left behind (Pratt, 2012; Pratt, https://blogs.ubc.ca/gpratt/publications/) Geographers in Singapore, (see, for example, Yeoh \& Huang, 2014) have carried out research with immigrant Southeast Asian women domestic workers and nurses coming from multiple source areas for employment to learn about their lives within multiple spaces and places. Their colleague, Kamalini Ramdas (2016), who identifies her own sexuality as queer, has reflected on the parameters of maintaining responsible academic and professional integrity while serving as research consultant in a project with Singapore-based Lesbian, Bisexual Transgender and Queer (LGBT) organization that was completing an assessment of Singaporean governmental policies with respect to the United Nations Convention on the Elimination of Discrimination Against Women. In engaging with policy and/or consultant roles, what standpoints does the researcher assume? 
Those who engage with gender and urban planning such as Israeli geographer, Tovi Fenster and her collaborators contribute to building community capacities (Fenster \& Eizenberg, 2016). Their sustained workshops have supported women's leadership in community regeneration workshops in Tel Aviv (Fenster \& Eizenberg, 2016) and her colleague Chen Misgav (2015) has engaged in social and political activism with LGBT groups (Misgav, 2015).

My own experiences include collaboration with the Institute for Women's Policy Research, an organization based in Washington DC and headed by an economist. Among its initiatives has been research with partners in various US states, building especially on local and particularly quantitative data on social and economic indicators to attend to variations across ethnic and socio-economic groups and sub-regions of the states that they are examining. Their work is disseminated to the national press and to relevant political advocacy bodies. My home state of Arizona was one of those selected for study and it was my task to identify and recruit community agencies, mostly those involved with the welfare of women, to engage with disseminating and drawing on the research to develop local programmatic activities as well as efforts to disseminate key findings through the local press and media. I reflected on some of the challenges of such work in Geojournal (Monk, 2006). A sustained engagement with colleagues in working at the US-Mexico border addressed gender and public health policies and services. These endeavors and experiences raise questions of how do we learn the skills to communicate beyond academia (Manning et al., 2004).

\section{Applications for Teaching Gender}

Let me conclude by moving from research to teaching. As researchers in gender studies have recognized that binaries of "male" and "female" can be over-simplifications and that other attributes play into ways people experience space and place so too is this perspective germane to teaching. In teaching a class in Barcelona that enrolled a diverse group of students Mireia Baylina and Maria Rodó created an activity that required students to identify graphically their degree of comfort in a variety of everyday settings - at home, on the street, on campus, on public transportation, in places of recreation and so on, creating a simulated a "relief map". Students then reflected on their individual maps and those of partners in the class. The activity generated an array of insights both into individual lives and those of different students reflecting their genders, sexuality, age, social class, and other differences. The exercise offers just one but clear example of the pervasive existence of such differences in individual lives. It has been published in the Journal of Geography in Higher Education offering opportunity for adaptation. It contributes to growing awareness and application of the significance of "intersectionalities," rather than simply binaries and how they are expressed and interpreted in diverse contexts. Indeed, the theme of intersectionalities yielded extensive participation in the international conference sponsored by the Gender Group at the Autonomous University of Barcelona in 2016. It attracted some 70 presenters from multiple countries from Iceland to New Zealand, Argentina to 
the Czech Republic, France to Brazil, the United States to India and others. They addressed themes such as mobilities, identities, religion in the secular city, environmental activism, access to housing, urban and rural life, planning issues, and relations in the classroom. The research methods ranged from use of GIS tools to interviews, observations, and interpretations of literature. If this seems like a conglomeration, I would rather say that it represents richness and creativity and recognition of the diversity of people, places and ways of knowing. Elsewhere I have also written of the strategies of a colleague then teaching in Arizona in a Women's Studies class that required students to enact what was labelled as an "outrageous act" - one that had to be approved in advance by the teacher as not harmful to the student but that would challenge norms and heighten the student's understanding of what others might experience.

Finally, let me note that the work is challenging but that there is much to do. There are themes that I see as understudied or needing to be further addressed. Though work with children and youth has emerged in some geographic arenas, attention in that field does not routinely attend to gender issues. Likewise perspectives on experiences over the life course, on aging, and on some ethnic groups, religious or refugee communities could use more attention. Most recently I have collaborated with colleagues in Australia to revisit communities where I did my doctoral research many years ago on social and economic aspects of people of indigenous or more specifically those of part-Aboriginal descent. We have been working with, rather than simply on local communities collaborating with local, agencies, training local people to engage with us in research, for example, in interviewing, and returning some materials including photographs to appropriate archives, local agencies, and families which I originally had contact so that they can both recall their own histories and assess the effects of policies that administrative governmental agencies are implementing. How has or can our work affect local lives, organization, and public policies? What might our research do to make any positive differences in the lives of those we study? We have published a booklet (Howitt, Colyer, Monk, Crew, \& Hull, 2016) prepared for local audiences and relevant agencies to see how conditions in the local communities have improved or not, over the period of the policy changes, in what ways and how they might differ across places. What might our research do to contribute to positive differences in the lives of those people we study? How might we generate such documents in addition to our more usual mode of writing yet another academic publication.

\section{REFERENCES}

Azmi, F., \& Lund, R. (2009). Shifting Geographies of House and Home: Female Migrants Making Home in Rural Sri Lanka. Journal of Geographical Science, 57, 33-54.

Blumen, O., Fenster, T., \& Misgav, C. (Eds). (2013). Bridging Gendered Diversity in a Globalizing World. Hagar, 11(1), 2-188.
Caretta, M. A. (2016). Member checking: A participatory method to test and analyze preliminary results in cross-cultural, cross language research. Qualittive Research, 16(3), 305-318.

Caretta, M. A., Drodzewski, D. J., Jokinen, C., \& Falconer, E. (2018). "Who can play this game?" The lived experiences of doctoral candidates and 
early career women in the neoliberal university. Journal of Geography in Higher Education, 42(2), 1-15. doi: 10.1080/03098265.2018.1434762

Chiang, L.-H. N. (2009). Volunteering: A Path to Integration by Taiwanese Middle-Class Female Immigrants in Canada. Journal of Geographical Science, 57, 71-96.

Fenster, T., \& Eizenberg, E. (2016). Planning with communities in regeneration projects: Toward a gendered civic capacity. Gender, Place and Culture, 23(9), 1254-1269.

Garcia-Ramon, M. D., \& Monk, J. (Eds.). (2007). Feminist geographies around the world. Belgeo, 3. Retrieved from https://journals.openedition.org/ belgeo/11103

Howitt, R., Colyer, C., Monk, J., Crew, D., \& Hull, S. (2016). Looking Forward - Looking Back: Changing social and economic conditions of Aboriginal people in rural NSW, 1965-2015. Sydney: Department of Geography and Planning, Macquarie University.

Garcia-Ramon, M. D., Castañer, M., \& Centelles, N. (1988). Geography in Spanish Universities. The Professional Geographer, 40, 307-315.

Huang, S., Monk, J., Fortujin, D. J., Garcia-Ramon, M. D., \& Momsen, J. H. (2017). A continuing agenda for gender: the role of the IGU Commission on gender and geography. Gender, Place and Culture, 24(7), 919-938.

Ibarra García, M. V., \& Escamilla-Herrera, I. (Coords.). (2016). Geografías Feministas de Diversas Latitudes [Feminist Geographies of Different Latitudes]. México: Universidad Nacional Autónoma de México, Instituto de Geografía.

Manning, P., Denman, C., \& Monk, J. (2004). En la búsqueda de un espacio común: Colaboración en la investigación y acción en la frontera México-Estados-Unidos [In the search for a common space: Collaboration in the investigation and action in the United States-Mexico borderline]. In C. Denman, J. Monk \& N. Ojeda de a Peña (Eds.), Compartiendo historias de fronteras: Cuerpos géneros, generaciones y salud [Sharing border stories: Genders, generations and health] (pp. 211-244). Hermosillo, MX: El Colegio de Sonora.

McDowell, L. (1979). Women in British Geography. Area, 11,151-54.

Mackenzie, S. (1989). The Status of Women in Canadian Geography. The Operational Geographer, 7(3), 2-8.
Misgav, C. (2015). With the current, against the wind: Constructing spatial activism and radical politics in Tel Aviv's LGBT Community Center. ACME: An International E-Journal for Critical Geography, 14(4), 1208-1234.

Monk, J. (2017). Washington Women: Practicing Geography in the U.S. Government, 1915-1970s. The Professional Geographer, 69(4), 683-93.

Monk, J. (2011). Perspectives on teaching geography and gender in a postsocialist, neoliberal-dominated world. International Research in Geographical and Environmental Education, 20(3), 165-167.

Monk, J. (2006). Choreographing a different dance: placing research in the public arena. Geojournal, 65, 249-261.

Monk, J. (2004). Teaching the "Other": Linking Knowledge, Emotion, and Action in Geographical Education. Hagar, Studies in Culture, Polity and Identities, 5(1), 11-21.

Monk, J., \& Garcia-Ramon, M. D. (2012). Bridges and Barriers: Some Cartographies of 'International Practice in Gender Studies. Querelles: Jahrbuch für Frauen und Gescherforschungen, Bd16. doi: $10.15461 / 14$

Monk, J., Manning, P., Denman, C., \& Cornejo, E. (2009). Place, positionality and priorities: Experts' views on women's health at the Mexico-US Border. Health \& Place, 15, 799-806.

Monk, J., \& Hanson, S. (1982). On Not Excluding Half of the Human in Human Geography. The Professional Geographer, 34(1), 11-23.

Pratt, G. (2012). Families Apart: Migrant Mothers and the Conflicts of Labor and Love. Minneapolis: University of Minnesota Press.

Ramdas, K. (2013). Contesting landscapes of familyhood: Singlehood, the AWARE Saga and Pink Dot celebrations. In E. L. E. Ho, C. Y. Woon \& K. Ramdas (Eds.), Changing Landscapes of Singapore: Old Tensions, New Discoveries (pp. 115-133). Singapore: NUS Press, Singapore.

Riaño, Y. (2016). Minga biographic workshops with highly skilled migrant women: enhancing spaces of inclusion. Qualitative Research, 16(3), 67-279.

Silva, J. M., Ornat, M. J., \& Chimin Junior, A. B. (Orgs.). (2017). Diálogos Ibero-Latino-Americana Sobre Geografias Feministas e das Sexualidades [Ibero-Latin American Dialogues on Feminist Geographies and Sexualities]. Ponta Grossa: Toda Palavra. 
Silva, J. M., Ornat, M. J., \& Chimin Junior, A. B. (Orgs.). (2016). Geografias Feministas e das Sexualidades: Encontros e Diferenças [Feminist and Sexuality Geographies: Meetings and Differences]. Ponta Grossa: Todapalavra.

Silva, J. M., \& Pinheiro da Silva, A. C. (Orgs.). (2011). Espaço, gênero e poder: conectando fronteiras [Space, gender and power: connecting borders]. Ponta Grossa: Todapalavra.

Voiculescu, S., \& Longhurst, R. (Eds). (2009). Post Socialism, Neoliberalism: Old and New Gendered Societies and Policies. Annals of West University of Timisoara, XIX, 1-146.
Yeoh, B. S. A., \& Ramdas, K. (2014). The place of migrant women and the role of gender in the cities of Asia. In S. Parnell \& S. Oldfield (Eds.), The Routledge Handbook of Cities of the Global South (pp. 370-385). UK: Routledge.

Yeoh, B., \& Huang, S. (2012). Home: paid domestic labour. In S. J. Smith (Ed.), International Encyclopedia of Housing and Home (pp. 451-455). Oxford: Elsevier.

Zelinsky, W. (1973). The Strange case of the Missing Female Geographer. The Professional Geographer, 25(1), 101-106. 